\title{
Best Conditions for the Production of Natural Isopentyl Acetate (Banana Aroma) from Cheese Industry Waste: An Experimental Precursor Approach
}

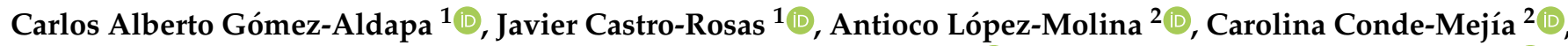 \\ Cuauhtémoc Francisco Pineda-Muñoz ${ }^{3}$, Angélica Jiménez-González ${ }^{3}{ }^{\circledR}$, Sergio Alejandro Medina-Moreno ${ }^{3}{ }^{\circ}$, \\ Martha Patricia Falcón-León ${ }^{3}$ and Laura Conde-Báez ${ }^{3, *(1)}$
}

check for updates

Citation: Gómez-Aldapa, C.A.; Castro-Rosas, J.; López-Molina, A.; Conde-Mejía, C.; Pineda-Muñoz, C.F.; Jiménez-González, A.; Medina-Moreno, S.A.; Falcón-León, M.P.; Conde-Báez, L. Best Conditions for the Production of Natural Isopentyl Acetate (Banana Aroma) from Cheese Industry Waste: An Experimental Precursor Approach Processes 2021, 9, 1880. https:// doi.org/10.3390/pr9111880

Academic Editors: Giannis Penloglou and Alexandros Kiparissides

Received: 18 September 2021

Accepted: 15 October 2021

Published: 21 October 2021

Publisher's Note: MDPI stays neutral with regard to jurisdictional claims in published maps and institutional affiliations.

Copyright: (c) 2021 by the authors. Licensee MDPI, Basel, Switzerland. This article is an open access article distributed under the terms and conditions of the Creative Commons Attribution (CC BY) license (https:// creativecommons.org/licenses/by/ $4.0 /)$.
1 Ingeniería en Química de Alimentos, Universidad Autónoma del Estado de Hidalgo, Carretera Pachuca-Tulancingo Km 4.5, Pachuca 42090, Hidalgo, Mexico; cgomeza@uaeh.edu.mx (C.A.G.-A.); jcastro@uaeh.edu.mx (J.C.-R.)

2 División Académica Multidisciplinaria de Jalpa de Méndez, Universidad Juárez Autónoma de Tabasco, Carretera Estatal Libre Villahermosa-Comalcalco Km 27 s/n, Ranchería Ribera Alta, Jalpa de Méndez 86205, Tabasco, Mexico; antioco.lopez@ujat.mx (A.L.-M.); carolina.conde@ujat.mx (C.C.-M.)

3 Ingeniería en Biotecnología, Universidad Politécnica de Pachuca, Ex-Hacienda de Santa Bárbara, Zempoala 43830, Hidalgo, Mexico; cuauhtemoc.pineda@hotmail.com (C.F.P.-M.); ajimenez@upp.edu.mx (A.J.-G.); samm67@upp.edu.mx (S.A.M.-M.); marthafalcon@upp.edu.mx (M.P.F.-L.)

* Correspondence: laura_conde@upp.edu.mx

Abstract: In some fermentation systems, whey components (lactose, proteins and minerals) can produce isopentyl acetate (IA). An analysis of the best conditions for IA production with Kluyveromyces marxianus was developed in this work. The experiment design was two-factor and three-level design based on a response surface methodology (RSM) using Design-Expert ${ }^{\circledR}$ software. The analysis of anomeric protons by nuclear magnetic resonance (1H-NMR) showed $81.25 \%$ of $\beta$ lactose content. This characteristic favored the production of IA. The maximum output (Mp) of IA, determined by gas chromatography, was $9.52 \mathrm{~g} / \mathrm{L}(p<0.05)$. The central composite design (CCD) was used to perform the factor analysis. Results showed that concentrations of $0.03(\mathrm{~g} / \mathrm{L})$ ammonium sulphate and $0.3(v / v)$ of isoamyl alcohol are the best conditions for a maximum rate of IA production. The production of IA can reduce the discharge of whey, allowing its reuse and revaluation.

Keywords: waste valorization; dairy industry; whey fermentation; anomeric protons; central composite design

\section{Introduction}

The effluent from cheese production in the dairy industry significantly impacts the environment because of its physicochemical characteristics [1]. It has been reported that the dairy industry generates a significant amount (400,000 million liters) of wastewater per year worldwide; whey is $50 \%$ of this amount [1,2]. As it has been reported, the biological treatment of whey through a conventional aerobic process is very costly, US $\$ 0.50 / \mathrm{kg}$ COD (chemical oxygen demand) [3]. Whey could be a renewable source to exploit, considering its high production (180 million tons) globally, due to more than $80 \%$ volume of processed milk. Among the main components of whey are the high lactose content $(30-60 \mathrm{~g} / \mathrm{L}, w / v)$ and $20 \%(w / v)$ protein, which contains approximately $50 \%$ of the present nutrients in milk [1]. The lactose content present in whey exceeds the limits set by the national and international regulations, generating adverse effects on the environment [4]. For most of the twentieth century, the industry has sought the cheapest whey disposal method, which has generally involved discharging it into waterways, municipal wastewater treatment, or open fields [3]. 
Conde et al. [5] presented an analysis on the content of $\beta$-lactose in sweet whey, which demonstrated advantages over the production of metabolites of industrial interest. This conformation could promote the formation of isopentyl acetate (IA), a short-chain fatty acid ester characterized by a strong banana smell [6]. Nowadays, the production of IA is mainly through the Fischer esterification method, which has among its disadvantages that the ester produced cannot be labeled as natural [7]. The toxicity of organic products is originated from the solvents used, the utilization of acids as catalysts, and the difficulty in extracting the compounds of interest [8]. On the other hand, the consumption of "natural" IA is increasing (75 tons per year) in industries such as pharmaceuticals and food mostly $[9,10]$. The "natural" aromas can be obtained only by: physical, enzymatic, or microbial processes, biocatalysis, novo synthesis (fermentation), and plants isolation [7]. Europe and the United States enable their safe use as additives $[8,9]$.

The biochemical production of IA has been achieved mainly through the synthesis of enzymes (lipases and esterases), reaching concentrations of up to $4 \mathrm{~g} / \mathrm{L}(v / v)[8,9]$. It has been reported that enzymatic synthesis is highly attractive. However, it results in selective processes that must have temperature control [11]. The novo synthesis is the preferential route to increase the number of fruity esters from sugars and alcohols in yeasts [12]. IA has been produced from various synthetic substrates (cassava bagasse, molasses, peptone, yeast extract, glucose, etc.). To the best of our knowledge, there is no report on the improvement of IA production in whey with the addition of ammonium sulfate and isoamyl alcohol. Consequently, in this work, the best conditions to increase IA production were determined by whey fermentation using Kluyveromyces marxianus yeast isolated from Agave durangensis. Biotechnological production would be an alternative to obtaining IA, contributing to the revaluation of the dairy industry residues, which harm the environment.

\section{Materials and Methods}

\subsection{Yeast Strain}

The K.marxianus ITD00262 strain, from the private collection of the Durango Institute of Technology, isolated by Páez et al. was used [13]. The strain was preserved on plates using Standar Methods Agar (Bioxon ${ }^{\mathrm{TM}}$-Guadalajara, Mexico) at $4{ }^{\circ} \mathrm{C}$ until use.

\subsection{Whey Preparation}

The samples were taken from the production of cheese. The dairy serum contained $0.73 \pm 0.05(\%, w / v)$ protein; $7.58 \pm 0.04(\%, w / v)$ easily-assimilable nitrogen (EAN); $0.49 \pm 0.082(\%, w / v)$ fat; $5.21 \pm 0.15 \mathrm{pH} ; 51.24 \pm 1.51$ total suspended solids (TSS, mg/L) were determined via an infrared spectrophotometric technique, using the Lactoscan MCC equipment (Milkotronic Ltd., Nova Zagora, Bulgaria). Whey was previously prepared by a LTLT process (Low Temperature, Long Time) $\left(63^{\circ} \mathrm{C} / 30 \mathrm{~min}\right)$. Subsequently, $\mathrm{pH}$ was adjusted to 4.8 using $1 \mathrm{~N} \mathrm{H}_{2} \mathrm{SO}_{4}$, and the $\mathrm{pH}$ was determined according to the norm NMX-F-317-S-1998. This step was performed at kinetics beginning to activate the lactose permease Lac12p and Lac4 $\beta$-cytosolytic galactosidase that hydrolyzes lactose into glucose and galactose [14]. The proximate analysis of whey was performed according to Conde et al. [14]. The quantification of nitrogen susceptible to be assimilated was determined according to the Kjeldahl method of the AOAC 930.52. $25 \mathrm{~mL}$ of whey was settled in digestion tubes $(250 \mathrm{~mL})$ [14].

\subsection{Isopentyl Acetate Production}

Whey, inoculated with $1 \times 10^{6}$ cells $/ \mathrm{mL}$ of $\mathrm{K}$. marxianus, was fermented in $250 \mathrm{~mL}$ bottles. It uses an isothermal process $\left(28^{\circ} \mathrm{C}\right)$ of constant volume $(150 \mathrm{~mL})$. The flasks were incubated in agitation $(180 \mathrm{rpm})$ at $28^{\circ} \mathrm{C}$ for $96 \mathrm{~h}$ (Shaker Thermo ${ }^{\circledR} \mathrm{TM} \mathrm{MaxQ}^{\mathrm{TM}}$ Scientific, Santa Clara, CA, USA). Every $24 \mathrm{~h}$, aliquots of $1 \mathrm{~mL}$ were taken from each flask, placed in sterile plastic (Eppendorf, Monterrey, Mexico) tubes, and stored at $-20^{\circ} \mathrm{C}$ until being analyzed by gas chromatography. The samples were analyzed in duplicate. The strain was pre-cultured in the medium, and was preserved in agar plates with standard 
methods (SMA) (standard methods (Bioxon, Guadalajara, Mexico-Agar) according to Conde et al. [14]. It was incubated for $12 \mathrm{~h}$ while maintaining an agitation of 1 Relative Centrifugal Force unit (RCF) or g-force at $30{ }^{\circ} \mathrm{C}$ (Shaker Thermo ${ }^{\circledR}$ Scientific, Santa Clara, CA, USA).

\subsection{Monitoring Process}

A yeast count was periodically performed from each flask by a viable stain with methylene blue (Innovating Science ${ }^{\mathrm{TM}}$, Rochester St., Avon, NY, USA) in a Neubauer chamber (Marienfeld-Superior ${ }^{\mathrm{TM}}$, Lauda-Königshofen, Germany). The lactose content throughout the fermentation was determined by the dinitrosalicylic acid (DNS) technique adapted from Horstch et al. [15]. Samples were prepared in triplicate, and centrifuged for 6 min before analysis. The equipment used was a centrifugal 9677 RCF (Eppendorf TM, Hamburg, Germany).

For the analysis of IA, the samples were centrifuged at 9677 RFC for $3 \mathrm{~min}$ in Eppendorf $^{\circledR}$ tubes. Subsequently, the samples were microfiltered and analyzed by gas chromatography with flame ionization detector (FID) (GC; Perkin Elmer ${ }^{\circledR}$, Santa Clara, CA, USA) equipped with a J\&W Scientific ${ }^{\circledR}$ DB-WAX column, Santa Clara, CA, USA $\left(60 \mathrm{~m} \times 0.25 \mathrm{~mm} \times 0.25\right.$ microns). The injector, detector, and oven worked at $230{ }^{\circ} \mathrm{C}, 250{ }^{\circ} \mathrm{C}$, and $140{ }^{\circ} \mathrm{C}$, respectively. The extract of the injected samples was $1 \mu \mathrm{L}$. Reference standards were used for the analysis of the samples. The samples were analyzed in triplicate.

\section{5. $1 H-N M R$}

For the analysis by nuclear magnetic resonance (NMR), the samples were previously centrifuged at 9677 RCF (Eppendorf ${ }^{\mathrm{TM}}$, Hamburg, Germany) for 6 min. Subsequently, a LTLT process was applied $\left(60^{\circ} \mathrm{C} / 30 \mathrm{~min}\right) .1 \mathrm{H}-\mathrm{NMR}$ spectra were obtained with a $\operatorname{Varian}^{\circledR}$ $400 \mathrm{MHz}$ spectrometer, Arizona, United States. Deuterium oxide $\left(\mathrm{D}_{2} \mathrm{O}\right)$ was used as a solvent. Five scans were performed to analyze proton NMR with a sequence $\mathrm{zg} 30\left(30^{\circ}\right.$ pulse before the evaluation of the spectrum) in an NMR Varian ${ }^{\circledR}$ equipment, $400 \mathrm{MHz}$ [12].

\subsection{Optical Rotation}

This analysis was determined with a Perkin Elmer ${ }^{\circledR}$, Inc 341 Polarimeter to determine the optimal rotation present in whey samples, complementing the NMR study. The equipment is provided with a sodium lamp adjusted to monochromatic radiation of $\lambda=589$ through a $1 \mathrm{dm}$ cell. The samples were prepared with $40 \mathrm{~mL}$ of sweet whey placed in conical propylene tubes and centrifuged at 9677 RCF (Eppendorf ${ }^{\mathrm{TM}}$, Hamburg, Germany) for $10 \mathrm{~min}$. The remainder was placed in a $250 \mathrm{~mL}$ ball flask and evaporated on a Buchi Rotavapor Water Bath ${ }^{\circledR}$ Darmstadt, Germany, B-480 at $80{ }^{\circ} \mathrm{C}$, using an average rotation. Subsequently, $60 \mathrm{mg}$ from the extract were dissolved in $2 \mathrm{~mL}$ of dimethyl sulfoxide (DMSO-d6). The specific rotation was calculated as follows:

$$
\left[\alpha_{o b s}\right]_{D}=\frac{100^{\circ} \propto}{1 \times C}
$$

where:

$\alpha$ is the optical rotation

$D$ is the monochromatic radiation sodium $(\lambda=589 \mathrm{~nm})$

1 is a decimeter long

$C$ is the sample volume

\subsection{Mathematical Modeling}

The mathematical modeling was determined for the maximum rates of production (rp) of IA from each treatment by correlating the experimental data of accumulated production at time t. Additionally, Gompertz differential equations for non-linear regression and the Levenberg-Marquardt algorithm according to Deseure et al. [16] were applied. The values of the coefficients of equation 2 were determined according to Conde et al. [5]. These 
values were used to obtain the coefficients $\left(\mathrm{A}, \mathrm{u}_{\mathrm{m}}\right.$ and $\left.\lambda\right)$ corresponding to the solution for Equation (3) [16]:

$$
y=a \cdot \exp [-\exp \exp (k-x c)]
$$

Solution of the Gompertz equation to $P_{\max }, r_{p}$ and $\lambda$, where:

$P_{\max }$ is the maximum production of IA obtained $(\mathrm{g} / \mathrm{L})$

$r_{p}(k / e)$ is the maximum rate of formation of IA $\left(\mathrm{h}^{-1}\right)$

$\left(x c-a / r_{p} \lambda_{+} e\right)$ is the cell duplication time $\left(\mathrm{h}^{-1}\right)$ and the Euler constant.

$$
y=P_{\max } \cdot \exp \left\{-\exp \left\{\frac{r_{p} \cdot e}{P_{\max }}\right\}(\lambda-t)+1\right\}
$$

\subsection{Scanning Electron Microscopy (SEM)}

The samples contained in Eppendorf ${ }^{\circledR}$ Safe-Lock Microcentrifuge tubes were prepared in a lyophilizer console (Labconco ${ }^{\circledR}$, Kansas City, MO, USA). Freeze drying conditions were at $-52{ }^{\circ} \mathrm{C}$ (capacitor) and vacuum pressure of 0.05 mbar. Samples were lyophilized for five hours and then prepared for SEM imaging, using a JEOL ${ }^{\circledR}$ JSM-6300 scanning electron microscope, with a current probe of $02 / 10$ to $10 / 05$ amperes (A) and a power of 2 to 30 kiloelectron volts $(\mathrm{keV})$.

\subsection{Statistical Analysis}

The CCD of two factors and three levels was applied in the study to find by optimizing conditions for IA production (see Table 1), using Design ${ }^{\circledR}$ Expert software (7.1.4.0) for the construction of a response surface evaluating the independent variables, and concentration of ammonium sulphate and isoamyl alcohol. The source of nitrogen available in whey for $K$. marxianus is $25 \%$; due to this, the utilization of ammonium sulfate used for its bioconversion in the Novo synthesis was considered [14].

Table 1. Levels of the factors used in the optimization of the maximum production rate of isopentyl acetate.

\begin{tabular}{lcccccc}
\hline Factor & Independent Variables & & \multicolumn{2}{c}{ Level } & & \\
& & $-\mathbf{1 . 4 1 4}(-\boldsymbol{\alpha})$ & $-\mathbf{1}$ & $\mathbf{0}$ & $\mathbf{1}$ & $\mathbf{1 . 4 1 4}(+\boldsymbol{\alpha})$ \\
\hline $\mathrm{X}_{1}$ & Isoamyl alcohol $(v / v)$ & 0.26 & 0.3 & 0.4 & 0.5 & 0.54 \\
$\mathrm{X}_{2}$ & Ammonium sulphate $(\mathrm{g} / \mathrm{L})$ & 0.026 & 0.03 & 0.04 & 0.05 & 0.054 \\
\hline
\end{tabular}

As a dependent variable for this case, the maximum IA production rate was considered (see Table 2). The distance for each axial point was $1.68\left(\alpha=2^{\mathrm{k} / 4}\right)$, considering $\mathrm{k}$ as the number of significances of the independent variables, while the number of experiments of such variables was calculated as $20(2 \mathrm{k}+2 \mathrm{~K}+4)$ [17]. The analysis of the variables was carried out according to the following equation:

$$
X_{1}=\left(U_{i}-U_{I}^{0}\right) \Delta U_{i}
$$

where:

$X_{1}$ is the independent variable codification,

$U_{i}$ represents the real value of the independent variable

$U_{I}^{0}$ is the center point independent variable 
Table 2. Speed of specific production of isopentyl acetate in different proportions of isoamyl alcohol and ammonium sulphate.

\begin{tabular}{|c|c|c|c|c|c|c|c|c|}
\hline \multirow{2}{*}{ Run } & \multicolumn{2}{|c|}{ Isoamyl Alcohol $\left(\mathrm{X}_{1}\right)$} & \multicolumn{2}{|c|}{ Ammonium Sulphate $\left(X_{2}\right)$} & \multirow{2}{*}{$\begin{array}{c}P_{\max }{ }^{a} \\
\text { Observed }\end{array}$} & \multirow{2}{*}{$\begin{array}{c}(\mathrm{g} / \mathrm{L}) \\
\text { Predicted }\end{array}$} & \multirow[t]{2}{*}{$\mathbf{r p}^{\mathbf{b}}$} & \multirow{2}{*}{$\begin{array}{c}(\mathrm{g} / \mathrm{L} \mathrm{h}) \\
\text { Actual }(v / v)\end{array}$} \\
\hline & Actual $(v / v)$ & Code & Actual (g/L) & Code & & & & \\
\hline 1 & 0.4 & 0 & 0.04 & 0 & 7.73 & 7.64 & 0.59 & 0.60 \\
\hline 2 & 0.4 & 0 & 0.054 & 1414 & 4.68 & 5.96 & 0.42 & 0.46 \\
\hline 3 & 0.3 & -1 & 0.05 & 1 & 8.02 & 7.14 & 0.30 & 0.31 \\
\hline 4 & 0.3 & -1 & 0.03 & -1 & 9.95 & 9.52 & 0.26 & 0.34 \\
\hline 5 & 0.4 & 0 & 0.04 & 0 & 8.12 & 7.64 & 0.56 & 0.60 \\
\hline 6 & 0.5 & 1 & 0.03 & -1 & 8.57 & 8.14 & 0.57 & 0.58 \\
\hline 7 & 0.4 & 0 & 0.026 & 1414 & 8.37 & 9.32 & 0.59 & 0.53 \\
\hline 8 & 0.4 & 0 & 0.04 & 0 & 7.65 & 7.64 & 0.69 & 0.60 \\
\hline 9 & 0.4 & 0 & 0.04 & 0 & 7.96 & 7.64 & 0.57 & 0.60 \\
\hline 10 & 0.5 & 1 & 0.05 & 1 & 6.22 & 5.76 & 0.58 & 0.51 \\
\hline 11 & 0.26 & -1.414 & 0.04 & 0 & 7.47 & 8.62 & 0.28 & 0.22 \\
\hline 12 & 0.4 & 0 & 0.04 & 0 & 8.76 & 7.64 & 0.60 & 0.60 \\
\hline 13 & 0.54 & 1.414 & 0.04 & 0 & 5.79 & 6.66 & 0.48 & 0.53 \\
\hline
\end{tabular}

Pmax $^{\mathrm{a}}$ : is the maximum IA production reached $(\mathrm{g} / \mathrm{L}), \mathrm{rpb}$ : is the maximum rate of isopentyl acetate formation.

In the optimization process, the response variable may relate to independent variables chosen through the following quadratic model:

$$
Y_{i}=\beta_{0}+\sum \beta_{i} x_{i}+\sum \beta_{i i} x_{i}^{2}+\sum \beta_{i j} x_{i} x_{j}
$$

where:

$Y_{i}$ values are the response predictions

$x_{i}$ are the parameters

$\beta_{0}, \beta_{i}, \beta_{i i}$ are the constant values. While $\beta_{i j}$ are the interactions of the coefficients.

The results were analyzed through a one-way variance analysis (ANOVA) by Fisher's Least Squares Deviation. The data were analyzed with the STATISTICA ${ }^{\circledR}$ software 8.0 considering a confidence level of $95 \%$. The least significant difference formula is shown below:

$$
\operatorname{LSD}_{A, B}=t_{\frac{0.05}{2}, D F W} \sqrt{m s w\left(\frac{1}{n_{a}}+\frac{1}{n_{b}}\right)}
$$

where:

$t$ is the critical value obtained from tables

$m s w$ is the average of the ANOVA value

$n$ is the number of tests

\section{Results}

The content of initial lactose for whey resulting from the casein coagulation by the action of renin at $\mathrm{pH} 6.5$ was $54 \mathrm{~g} / \mathrm{L}(w / v)$. Some authors have reported similar lactose concentrations for this type of whey ranging from 46 to $56 \mathrm{~g} / \mathrm{L}(w / v)$ [18]. Furthermore, the anomeric conformation for substances with lactose was almost not reported [18]. In this paper, the whey extraction with DMSO resulted in a white solid $(14 \mathrm{mg}, 0.17 \%)$ that showed an optical rotation of +28 , using monochromatic radiation of $\Lambda-589 \mathrm{~nm}$ at $20{ }^{\circ} \mathrm{C}$. These results indicate the presence of a dextrorotatory molecule. The solid was physically and spectroscopically characterized; additionally, it was compared with data for $(+)$ - $\beta$-lactose and (+)- $\alpha$-Lactose mixture [19].

It was determined using NMR spectrum that the content of $\beta$-lactose was $81.25 \% \pm 0.81$ and $0.36 \% \pm 17.64$ for $\alpha$-lactose. These results are associated with the $\mathrm{pH}$ of sweet whey that favors the nucleation process by increasing the conversion rate of $\alpha$ and $\beta$ anomers, increasing solubility $[7,19]$. Conversion between these forms of lactose is highly dependent on temperature, the presence of salts, and lactose concentration in whey [19]. Scanning electron microscopy (SEM) showed the microstructure of whey as a matrix of rough ap- 
pearance of the porous and open protein network. In this matrix, numerous fat globules of varying size and hemispherical shape were uniformly distributed (Figure 1).

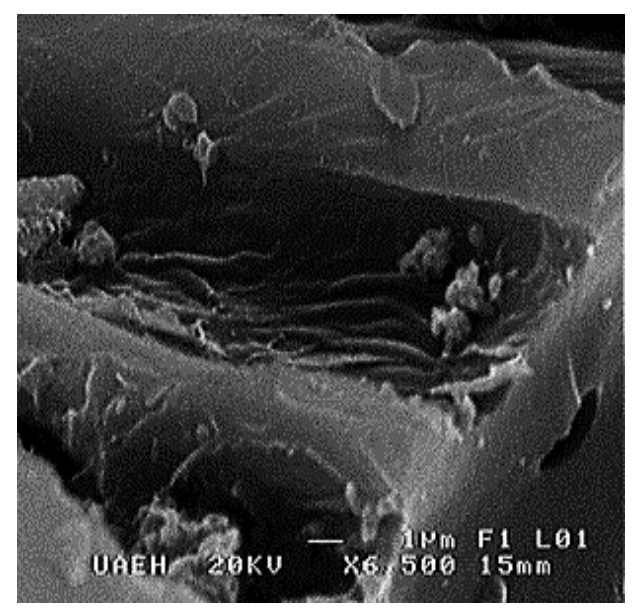

(a)

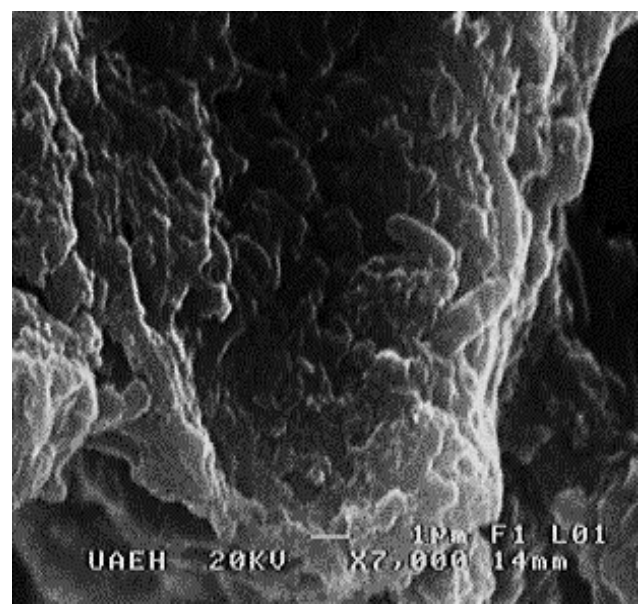

(b)

Figure 1. Micrograph of the whey microstructure: (a) without biofilm K. marxianus and (b) scanning of the optimal conditions for IA production in whey, time of $48 \mathrm{~h} \mathrm{~K}$. marxianus biofilm formation.

The presence of the proteins in whey through the water-binding contributes to the nucleation process, creating areas of saturation. This process has already been described through some kinetic models [20]. The phase transitions and their effect on matrix properties analysis allow establishing a factorial design. Then, the conditions improve the K. marxianus intracellular enzyme performance, allowing the use of lactose as a carbon source [21]. This favored the IA production increase.

Gas chromatography (GC) showed a maximum production $\left(\mathrm{P}_{\max }\right) 9.56$ to IA g/L (treatment 4 ) at $48 \mathrm{~h}$. These results contrast to those by Texeira et al. [22], who obtained an IA concentration of $0.17 \mathrm{~g} / \mathrm{L}$. On the other hand, Calleros et al. [23] obtained an IA concentration of $0.23 \mathrm{~g} / \mathrm{L}$ in serum of whey (tofu). The results could be caused by the $\beta$-lactose content and ammonium sulphate with the supplement as EAN source promoting the alcohol acetyltransferase (AATase) metabolic pathway [24]. This route, which generates the production of esters from fatty acids present in whey during fermentation, allows the formation of IA by transfer of functional groups [25]. In addition, the increase in IA production was favored by adding isoamyl alcohol through the metabolic pathway to both the synthesis de novo and the Ehrlich Pathway [7,9]. Conde et al. [5] showed the production of ethanol in sweet whey of $15.59(\mathrm{~g} / \mathrm{L})$ in the production of 2-phenylethanol (2-PEA). In this work, a concentration of $6.24 \mathrm{~g} / \mathrm{L}$ was obtained $(24 \mathrm{~h})$. The high production of ethanol has been reported to contribute to the formation of acetaldehyde converted to isoamyl aldehyde and finally reduced to IA through the route that involves the formation of higher alcohols [21].

The optimum levels of the key factors in the production rate of isopentyl acetate were determined by design (RSM) response surface methodology. Table 3 shows the specific results of the experimental design of the variable design matrix. 
Table 3. ANOVA results for the quadratic polynomial model response surface.

\begin{tabular}{cccccc}
\hline Source & Sum of Squares & $\mathbf{D}_{\mathbf{f}}$ & Mean Square & F-Value & $p$-Value \\
\hline MODEL & 0.2044 & 5 & 0.0409 & 8.6 & 0.0067 \\
$\mathrm{X}_{1}$ & 0.0977 & 1 & 0.0977 & 20.55 & 0.0027 \\
$\mathrm{X}_{2}$ & 0.0049 & 1 & 0.0049 & 1.03 & 0.3442 \\
$\mathrm{X}_{1} \mathrm{X}_{2}$ & 0.0002 & 1 & 0.0002 & 0.0398 & 0.8476 \\
$\mathrm{X}_{12}$ & 0.091 & 1 & 0.091 & 19.13 & 0.0033 \\
$\mathrm{X}_{22}$ & 0.02 & 1 & 0.02 & 4.21 & 0.0793 \\
Residual & 0.0333 & 7 & 0.0048 & & \\
Adjustment & 0.0233 & 3 & 0.0078 & 3.09 & 0.1519 \\
Pure Error & 0.01 & 4 & 0.0025 & & \\
Cor Total & 0.2377 & 12 & & & \\
\hline
\end{tabular}

$\mathrm{R}^{2}: 90.0 \%$, Coefficient of variation $(\mathrm{CV}): 13.0 \%$.

A second-order polynomial regression equation shows the dependence of the maximum rate of formation of ammonium sulphate and IA with the isoamyl alcohol. The multiple regression analysis of the experimental data allowed us to determine the parameters used in the following polynomial equation:

$$
Y=0.603+0.110 x_{1}-0.024 x_{2}-0.006 x_{1}^{2}-0.114 x_{2}^{2}-0.053 x_{1} x_{2}
$$

where:

$Y$ is the prediction of the response variable

$x_{1}$ are the values of the independent variables

$X_{1}$ (isoamyl alcohol) and $x_{2}$ is the encoded value of the variable $X_{2}$ (ammonium sulphate)

This equation was optimized by using the method of interaction (SigmaPlot 12.5 software). The model coefficients were estimated by linear regression, where the value of $(p)$ was required for assessing the significance of each coefficient. In this work, the individual effects of $X 1$ and $X_{1}^{2}$ showed significance $(p<0.05)$ for the production of IA, with a coefficient estimated at $0.11 X_{1}$ and -0.006 to $X_{1}^{2}$ Equation (7). The higher the value of $(t)$ and the lower the value of $(p)$, the value of the corresponding coefficient has greater significance [26]. The significance of the coefficients was determined through the Student t-distribution, while the $p$ values are shown in Table 3.

The validation of the model was carried out through the analysis of the residuals with a confidence interval of $95 \%$; the significant differences of the statistical model were determined by means of an analysis of variance (ANOVA) F-test. The regression adjustment is still significant at $p<0.005$, which is adequate to represent the relationship between IA production and the independent variables. The coefficients estimation by a linear regression model, based on the effect of the variables, resulted in the following equation:

$$
Y=7.64-0.694 x_{1}-1.19 x_{2}
$$

where:

$Y$ is the prediction of the response

$x_{1}$ is the encoded value of the variable $X_{1}$ (isoamyl alcohol), and $x_{2}$ is the encoded value of the variable $X_{2}$ (ammonium sulphate)

The independent variables showed optimal values for achieving the maximum rate production of IA of $0.63 \mathrm{~g} / \mathrm{L} \mathrm{h}$ are $0.45(v / v)$ for $X_{1}$ and $0.037(\mathrm{~g} / \mathrm{L})$ for $X_{2}$ the quadratic model for rp; Pmax was obtained at maximum concentration with the linear model of $9.52 \mathrm{~g} / \mathrm{L}$ in $X_{1}=0.3(v / v)$ and $X_{2}=0.03(\mathrm{~g} / \mathrm{L})$ (Figure 2). 


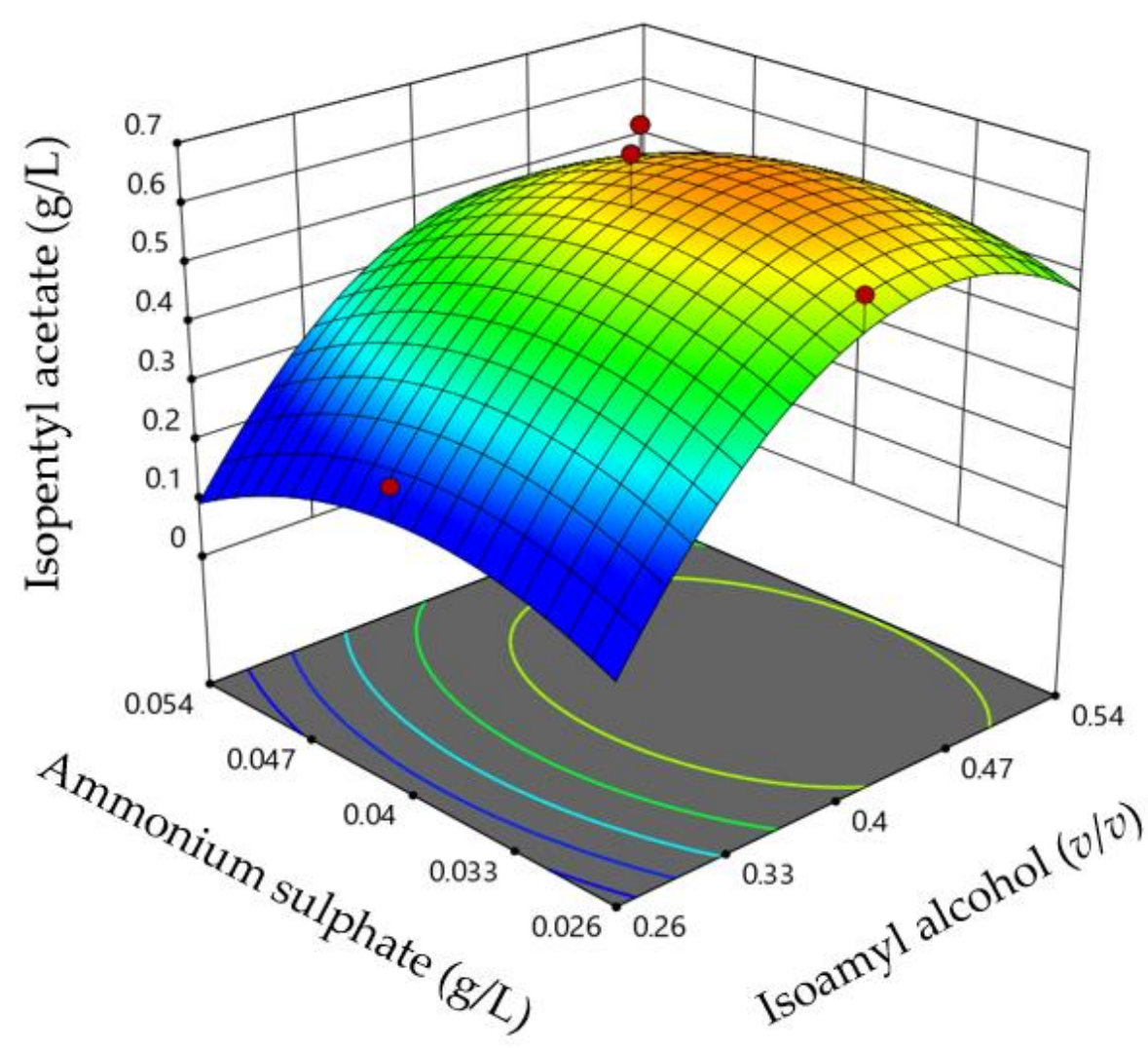

Figure 2. The response surface plots showing the effects of independent variables on the $r_{p}$.

According to the two-dimensional contour plot, the process can be more sensitive to changes in the concentration of isoamyl alcohol than to changes in the concentration of ammonium sulphate, with a coefficient estimated at -1.19 to $\mathrm{X}_{2}$ Equation (8). For these conditions, the scanning electron microscope (SEM) showed a time of $48 \mathrm{~h}$, where it has the highest rate of IA production and the formation of biofilm K.marxianus, with a $6.98 \times 10^{6}$ count CFU / mL. This could be due to protein aggregates of tiny particles of heatcoagulated whey protein, with diameters of 1 to $2 \mu_{m}$ [27]. The K. marxianus microstructure shows several similarities to that reported by Cabaroglu et al. [28].

\section{Conclusions}

In this study, the most favorable conditions reported to date were found for the biotechnological production of isoamyl acetate, a product of high commercial value, from whey. Ammonium sulphate and isoamyl alcohol concentrations were analyzed as independent variables in IA production. The data were analyzed using the response surface technique (RSM). The concentrations of $0.3(v / v)$ of isoamyl alcohol and $0.03(\mathrm{~g} / \mathrm{L})$ of ammonium sulfate generated the maximum concentration of IA, which corresponded to $9.52 \mathrm{~g} / \mathrm{L}$. So far, this is the highest reported IA concentration value at the exit of a fermentation. The bromatological and SEM analysis of whey identified three critical issues: whey physicochemical properties, the enzymatic coagulation type, and the protein concentration. Sweet whey is a good source of carbon in fermentation processes. Compared with other types of whey (acid/curd), sweet whey has high $\beta$-lactose content, increasing its solubility and allowing its bioconversion to interest metabolites at an industrial level. The presence of this dextrogyrous molecule that participates in the nucleation process was validated with polarimetry analysis. 
Author Contributions: Contribution: investigation, C.A.G.-A., J.C.-R., A.L.-M., C.C.-M., A.J.-G., S.A.M.M. and L.C.-B.; methodology, C.A.G.-A., C.F.P.-M., M.P.F.-L.and L.C.-B.; visualization, C.A.G.-A. and J.C.-R.; writing - original draft, A.L.-M., C.C.-M. and L.C.-B.; writing-review and editing, A.L.-M., C.C.-M. and L.C.-B. All authors have read and agreed to the published version of the manuscript.

Funding: The research received no external funding.

Institutional Review Board Statement: Not applicable.

Informed Consent Statement: Not applicable.

Data Availability Statement: No extra data are available.

Acknowledgments: C.C.-M. acknowledges support by PRODEP project UJAT-PTC-288.

Conflicts of Interest: The authors declare no conflict of interest.

\section{References}

1. Asunis, F.; Giorgia, G.; Paolo, D.; Marco, I.; Piet, N.; Aldo, M.; Alessandra, P.; Raffaella, P.; Andreina, R.; Daniela, S. The dairy biorefinery: Integrating treatment processes for cheese whey valorisation. J. Environ. Manag. 2020, 276, 111-240. [CrossRef]

2. Dessı, P.; Asunis, F.; Harish, R.; Francesco, G.; Cocco, G.; Aldo, M.; Piet, N.; Lens, L. Fermentative hydrogen production from cheese whey with in-line, concentration gradient-driven butyric acid extraction. Int. J. Hydrog. Energy 2020, 45, 24453-24466. [CrossRef]

3. Guo, D.; Sijia, K.; Hong, P.; Xiaoyun, L.; Xun, L. De novo biosynthesis of 2-phenylethanol in engineered Pichia pastoris. Enzym. Microb. Technol. 2020, 133, 10941-10959.

4. Paulino, B.N.; Sales, A.; Felipe, L.; Pastore, G.M.; Molina, G.; Bicas, J.L. Recent advances in the microbial and enzymatic production of aroma compounds. Curr. Opin. Food Sci. 2021, 37, 98-106. [CrossRef]

5. Conde, B.L.; Castro, R.J.; Villagómez, I.J.R.; Páez, L.J.B.; Gómez, A.C. Evaluation of waste of the cheese industry for the production of aroma of roses (phenylethyl alcohol). Waste Biomass Valorization 2016, 8, 1343-1350. [CrossRef]

6. Rao, R.; Basak, N. Optimization and modelling of dark fermentative hydrogen production from cheese whey by enterobacter aerogenes 2822. Int. J. Hydrog. Energy 2021, 46, 1777-1800. [CrossRef]

7. Soto, I.N.; Araiz, C.O.; Martínez, L.E.; Barragán, P.A.; Ochoa, S.H. Solid/gas biocatalysis for aroma production: An alternative process of white biotechnology. Biochem. Eng. J. 2020, 164, 107767. [CrossRef]

8. Azudin, N.Y.; Sangaran, S.; Shukor, S.R.A. Non-enzymatic synthesis route for production of isoamyl acetate in a solvent-free system using miniaturized intensified reactor. J. Environ. Chem. Eng. 2019, 8, 103186. [CrossRef]

9. Sánchez, C.A.K.; Athés, V.; Moussa, M.; López, M.J.; Páez, L.J.B.; Soto, C.O.N.; Trelea, I.C. Modeling of isoamyl acetate production by fermentation with Pichia fermentans in an aerated system coupled to in situ extraction. Process. Biochem. 2018, 65, 11-20. [CrossRef]

10. Zare, M.; Golmakani, M.-T.; Niakousari, M. Lipase synthesis of isoamyl acetate using different acyl donors: Comparison of novel esterification techniques. LWT 2019, 101, 214-219. [CrossRef]

11. Aïder, M.; Ahasanul, K.; Natela, G. Kluyveromyces marxianus: An emerging yeast cell factory for applications in food and biotechnology. Int. J. Food Microbiol. 2020, 333, 10881-10888.

12. Faccia, M.; Trani, A.; Natrella, G.; Gambacorta, G. Short communication: Chemical-sensory and volatile compound characterization of ricotta forte, a traditional fermented whey cheese. J. Dairy Sci. 2018, 101, 5751-5757. [CrossRef]

13. Páez, L.J.B.; Arias, G.A.; Rutiaga, Q.O.; Barrio, E.Q.; Soto, C.N. Yeasts isolated from the alcoholic fermentation of Agave durangensis during mezcal production. Food Biotecnol. 2010, 4, 27-34.

14. Conde, B.L.; López, M.A.; Gómez, A.C.A.; Pineda, M.C.F.; Conde, M.C. Economic projection of 2-phenylethanol pro-duction from whey. Food Bioprod. Process. 2019, 115, 10-19. [CrossRef]

15. Hortsch, R.; Löser, C.; Bley, T. A two-stage CSTR cascade for studying the effect of inhibitory and toxic substances in bioprocesses. Eng. Life Sci. 2008, 8, 650-657. [CrossRef]

16. Deseure, J.; Obeid, J.; Willison, C.J.; Magnin, J.P. Reliable determination of the growth and hydrogen production param-eters of the photosynthetic bacterium Rhodobacter capsulatus in fed batch culture using a combination of the Gompertz function and the Luedeking-Piret model. Heliyon 2021, 7, e07394. [CrossRef]

17. Santhosh, A.J.; Tura, A.D.; Jiregna, I.T.; Gemechu, W.F.; Ashok, N.; Ponnusamy, M. Optimization of CNC turning parameters using face centred CCD approach in RSM and ANN-genetic algorithm for AISI 4340 alloy steel. Results Eng. 2021, $11,100251$. [CrossRef]

18. Salcedo, P.S.I.; Calla, C.A.; Aliaga, A.M.T.; Melgar, C. CF Volatile ester production using citrus waste through fermenta-tion technology. Rev. Cienc. 2016, 4, 83-91.

19. Arrizon, J.J.; Ñeco, C.V.; Cervantes, V.F.; Delgado, L.A.; Ballesteros, A.O.; Plou, F.J. Synthesis of b(1 $\rightarrow 3)$ and b(1 $\rightarrow 6)$ galactooligosaccharides from lactose and whey using a recombinant b-galactosidase from Pantoea anthophila. Electron. J. Biotechnol. 2021, 49, 14-21. 
20. Jawad, R.; Drake, A.F.; Elleman, C.; Martin, G.P.; Warren, F.J.; Perston, B.B.; Ellis, P.R.; Hassoun, M.A.; Royall, P.G. Stability of sugar solutions: A novel study of the epimerization kinetics of lactose in water. Mol. Pharm. 2014, 11, 2224-2238. [CrossRef] [PubMed]

21. Altamimi, M.J.M.A.; Wolff, K.; Nokhodchi, A.; Martin, G.P.; Royall, P.G. Variability in the $\alpha$ and $\beta$ anomer content of commercially available lactose. Int. J. Pharm. 2019, 555, 237-249. [CrossRef]

22. Texeira, R.M. Endless versatility in the biotechnological applications of Kluyveromyces marxianus LAC genes. Biotechnol. Adv. 2009, 24, 212-225. [CrossRef]

23. Calleros, C.L.; Ivanhoe, L.C.; Vernon, C.E.J. Texture and microstructure of low-fat and low-cholesterol panela type cheeses: Different methodologies. Ing. Agríc. Biosist. 2009, 1, 39-48.

24. Lee, J.-W.; Trinh, C.T. Towards renewable flavors, fragrances, and beyond. Curr. Opin. Biotechnol. 2020, 61, 168-180. [CrossRef]

25. Yong, J.C.; Lu, Y.; Quan, S.L. Evaluation of five commercial non-Saccharomyces yeasts in fermentation of soy (tofu) whey into an alcoholic beverage. Food Microbiol. 2018, 76, 533-542.

26. Santos, D.P.; Angela, M.; Meireles, A.; Julian, M. Production of isoamyl acetate by enzymatic reactions in batch and packed bed reactors with supercritical $\mathrm{CO}_{2}$. J. Supercrit. Fluids 2017, 127, 71-80. [CrossRef]

27. Barney, B.M. Metabolic engineering: The sweet smell of biosynthesis. Nat. Chem. Biol. 2014, 10, 246-247. [CrossRef] [PubMed]

28. Yilmaztekin, M.; Erten, H.; Cabaroglu, T. Enhanced production of isoamyl acetate from beet molasses with addition of fusel oil by Williopsis saturnus var. saturnus. Food Chem. 2009, 112, 290-294. [CrossRef] 